\title{
EXAMINATION OF PERFORMANCE MANAGEMENT TARGETS IN CASE OF AN INTERNATIONAL CORPORATION'S EASTERN HUNGARIAN OPERATING UNIT
}

\author{
Nemeth Zoltan \\ Dajnoki Krisztina \\ Suto David \\ Fenyves Veronika \\ University of Debrecen, Hungary \\ E-mail: fenyves.veronika@econ.unideb.hu
}

(Received November 2015; Accepted February 2016)

\begin{abstract}
Nowadays, due to the social and economic changes, the human is already the main resource which determines the successfulness of corporations. The expertise in managing the human resources is a key factor of competitiveness therefore it has become a strategic question. Primary aim of the treatise is to outline the most important principles, targets and peculiarities of performance management system, which is a central element of human resource management, as well as its interconnectedness with the individual performance evaluation and human resource development through the mirror of one of today's biggest Hungarian economic corporations. We aimed to explore, by means of document analysis as well as methods of case study and interview, how the targets of performance management are used for increasing the economic productivity, preserving the competitiveness, retaining and enhancing the satisfaction of workers. It can be stated that the PM system was continuously improved in case of the organization examined because the corporate goals and the expected performances were adjusted to the changing market demands over time but, at the same time the goal of differentiation has remained unchanged. Each worker evaluates his/her performance individually, the base of which is the extent of contribution to the corporate results. Based on the results, it can overall be stated that such a well-functioning performance management system is applied in the operating unit of the corporation examined which is strongly supported by the organizational culture and which contributes to the joint fulfilment of personal as well as organizational goals.
\end{abstract}

Key words: human resource, performance appraisal, development, SMART, EMS J.E.L. CODES: M51, M54

\section{Introduction}

Today, it is accepted that the skills, knowledge, commitment and motivation of workforce form a significant part of the national and corporate capital. The performance management system is such a systematic approach of managing the people, which uses the performance, goals, measurement, feedback and 
Németh Z., Dajnoki K., Sütő D., Fenyves V. (2016)

Examination of performance management targets in case of an international corporation's eastern hungarian operating unit

appreciation as tools in motivation for the maximum utilization of employee potential.

Primary aim of the treatise is to outline the most important principles, targets and peculiarities of performance management system, which is a central element of human resource management, as well as its interconnectedness with the individual performance evaluation and human resource development through the mirror of one of today's biggest Hungarian economic corporations.

\section{Literature review}

The organizations could never operate without the fundamental factors of production and the human resources enshrined among them. Effective human resource management can help ensure that we get results - through people (Dessler, 2013).

The strategic human resource management focuses on organizational performance, but strategic means more than a system focus or even financial performance: strategy is about building sustainable competitive advantage that in turn creates above-average financial performance. (Becker-Huselid, 2006) Appreciation of the people's role in the organizational competitiveness gives a new opportunity to manage them. Not only among the researchers but also among the practitioners, including the managers (Bacsne, 2012), more and more people emphasize that the activities and decisions relating to the human resources should be considered as investment rather than enumerating them according to cost factors (Karolinyne, 2010). According to Senyucel (2009) the tighter budgets, unpredictable employee markets, a dissatisfied and demotivated workforce put strains on effective delivery of human resource management.

It also plays a role respect of hygiene and occupational safety norms with adequate protection, implementation of specific programs for workplace health promotion. Very important is the aspect of health education, awareness of the workers (Jebereanu et al., 2013).

Human resource development projects have several components, namely: sustainability, equality, sustainable development, innovation and information and communication technology, and interregional approach (Draganescu et al., 2013).

Performance measurement shall be connected to the human resources strategy, mission and targets i.e. it is worth creating a strategical map which help to determine the key performance indicators (KPI). All these ones are complicated and time-consuming but it is recommended for every organization to take this step because it can guarantee the competitiveness and flexibility (Iveta, 2012).

An operating performance evaluating system is already a significant result in itself for an organization but there are also conditions for a program working effectively.

24 DE GRUYTER OPEN
Studia Universitatis "Vasile Goldis" Arad. Economics Series Vol 26 Issue 2/2016 ISSN: 1584-2339; (online) ISSN: 2285 - 3065.

Web: publicatii.uvvg.ro/index.php/studiaeconomia.Pages $23-37$ 
Németh Z., Dajnoki K., Sütő D., Fenyves V. (2016)

Examination of performance management targets in case of an international corporation's eastern hungarian operating unit

Max - Bacal (2002) emphasize that the most important task is to familiarize the employee with the essential rules about what he/she is entitled to do i.e. in what a given worker is competent during his/her work and how he/she shall cooperate with others.

According to Sartain (2004), the extraordinary results are produced by people having extraordinary attitude and not by employees who are extraordinarily qualified or experienced. The most qualified "star candidate" possessing the biggest experience and practice can be employed but it does not mean that he/she will become a star employee automatically. Certain traits can be influenced, formed but, unfortunately, none of them can be evolved out of nothing effectively and in a short time. The adequate performance appraisal system plays an important role in retaining talent too (Allen, 2008). According to Snell - Bohlander (2003), the motivations and efforts of a person are defined by the following: how the set targets can motivate him/her, what place the job occupies in his/her life, how satisfied he/she is with himself/herself and his/her results achieved, what relation he/she has with his/her colleagues.

A survey by Gergely - Dienesne (2010) shows that both managers and subordinates find harmonizing the performance management and motivation system necessary. It is important that communication should get sufficient role in the process of performance management. It is essential to tell the appraised the objective precisely, which may help in evolving confidence between managers and employees.

According to Laezar (2009), aim of the performance evaluation is to provide information about the workers' general as well as specific skills and performances. By this, the organization gets information about the necessity of investing in human capital. In possession of this information, the organizations make decisions about the individuals' training, promotion or possible dismissal. Namely, applying an employee for the proper job is an interest of both the individual and the organization as well.

According to Pulakos (2004) the "Achilles' Heel" of human resource management is the performance management system, which includes performance appraisal and employee development. A survey showed that only $30 \%$ of employees agree that their company's performance management system helps improve performance. Less than four out of ten workers said their system established clear performance goals, generated honest feedback and or used technology to streamline the process. McKenna - Beech (1995) also confirm that it is important that the manager should try to establish congruence between the individual and organizational targets during the evaluation. Performance management is an improved version of the performance evaluating system which eliminates the defect and problem of the 
Németh Z., Dajnoki K., Sütő D., Fenyves V. (2016)

Examination of performance management targets in case of an international corporation's eastern hungarian operating unit

traditional evaluating system.

Performance management is a systematic procedure for improving the organizational performance as well as the performance of the person and group progress as well (Armstrong, 2006a). What we call performance management process is the unified system of the target, performance measurement and evaluation, feedback, follow-up; the aim of this system is to establish a harmony between the individual performance and the corporate strategic goals (Dessler, 2012).

The aims of performance management as expressed by a variety of organizations are the following (IRS, 2003 In Armstrong 2006b):

- Armstrong World Industries: empowering, motivating and rewarding employees to do their best.

- Eli Lili \& Co: focusing employee's tasks on the right things and doing them right. Aligning everyone's individual goals to the goals of the organization.

- ICI Paints: proactively managing and resourcing performance against agreed accountabilities and objectives.

- Standard Chartered Bank: the process and behaviours by which managers manage the performance of their people to deliver a high-achieving organization.

- West Bromwich Building Society: maximizing the potential of individuals and terms to benefit themselves and the organizations, focusing on achievement of their objectives.

Figure 1 shows the possible outcomes from effective performance management.

Success requires the motivation of performance or, as it is sometimes called, the outcome demands. The examinations, which indicate that the performing top managers are compared to the average ones, are showing that the best managers demonstrate the following signs of the performance motivation competence: they take more calculated risks, they urge and support the enterprising innovations, they set out challenging goals for their subordinates and their support helps the novel ideas of others. The largest differences between the outstanding and average top managers show themselves in the competency of outcome demands. (Spencer, L. Spencer, S., 1993)

According to Goleman (2002), the performance motivation is no other than an aspiration for reaching or exceeding the excellent level. Those who have this competence are result-oriented, are motivated to reach their goals and, at the same time, to comply with the rule; they set themselves incentive targets and they take calculated risks, they actively search for information decreasing their doubtfulness, they find the opportunity to develop and they learn to improve their performance. Utilizing the extraordinary performance of labour force is possible only if the managers believe in it. Their task is to provide their subordinates with adequate

26 DE GRUYTER OPEN
Studia Universitatis "Vasile Goldis" Arad. Economics Series Vol 26 Issue 2/2016 ISSN: 1584-2339; (online) ISSN: 2285 - 3065.

Web: publicatii.uvvg.ro/index.php/studiaeconomia.Pages $23-37$ 
Németh Z., Dajnoki K., Sütő D., Fenyves V. (2016)

Examination of performance management targets in case of an international corporation's eastern hungarian operating unit

sources, support and freedom in order to be able to use the opportunity if that particular moment comes. (Sartain, 2004)

Figure 1 Possible Outcomes from Effective Performance Management

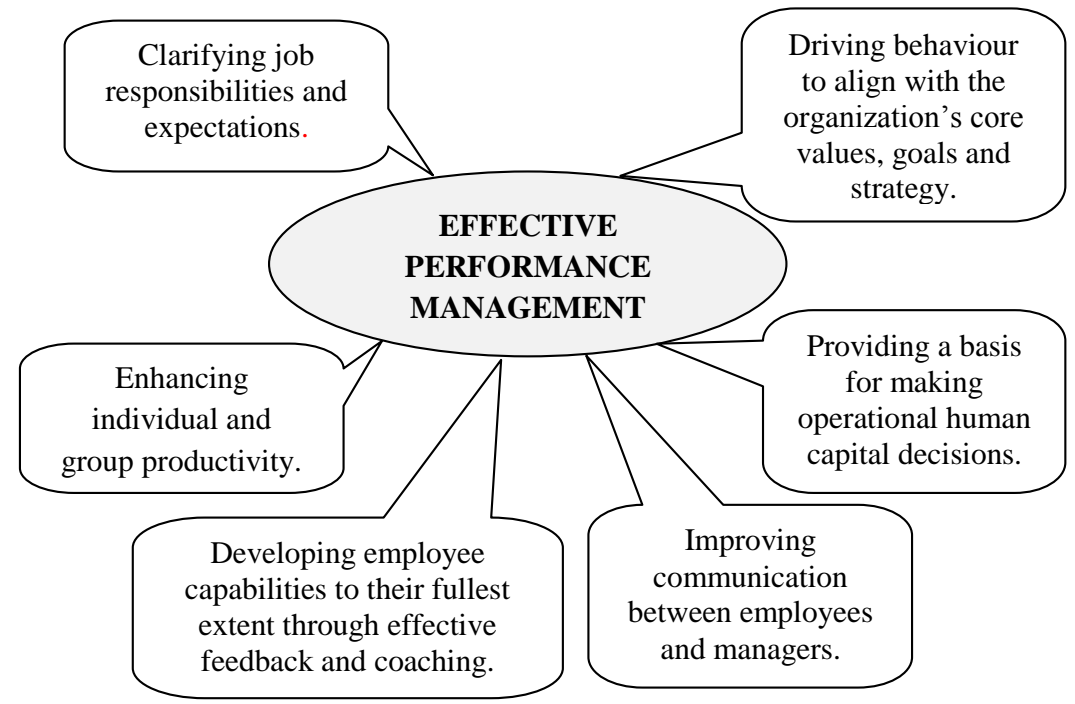

Source: Pulakos (2004)

\section{Material and methods}

Establishment of the organization goes back to the end of 1880 s. All five main divisions of the organization having its parent company in the United States of America can be found in Hungary. Nowadays, the company examined is one of the largest American employers (more than 12000 employees) and investors as well as one of the biggest exporters in Hungary. The key to the company's successful activity in Hungary is the cooperation with the local communities, the business and scientific communities as well as the government. In Europe, the company currently operates 6 factories and five of these ones can be found in Hungary.

The operating unit examined has been operating in Hungary since the 1970s. $71 \%$ of the employees are female and $29 \%$ are male. The average service period of the workers exceeds 19 years and, in addition, the average age is almost 45. Based on this, it can be said that very committed employees work for the company. It is peculiar to the professional qualifications, due to the nature of workflows, that $69 \%$ of the employees perform semis-killed work, $25 \%$ of them carry out skilled works and only $6 \%$ of them have higher education qualifications.

For the examinations, we have used the fundamental method of qualitative research 
Németh Z., Dajnoki K., Sütő D., Fenyves V. (2016)

Examination of performance management targets in case of an international corporation's eastern hungarian operating unit

techniques i. e. the document analysis as analysing method, the essence of which is to explore those coherences and peculiarities which can be found in the documents. This retrospective research method can be used, in the most effective way, for the subsequent use and analysis of the documents prepared already. For the in-depth and longitudinal examinations, we have used the case study as a research method of the social sciences. This has offered us an opportunity to examine the data systemically, to collect information, to analyse and record the final results. Expert interviews have helped to process and understand the results.

\section{Results}

\subsection{Targets for application of performance management}

The PM system was continuously improved in case of the organization examined because the corporate goals and the expected performances were adjusted to the changing market demands over time but, at the same time, the goal of differentiation has remained unchanged. Each worker evaluates his/her performance individually, the base of which is the extent of contribution to the corporate results. The individual performance evaluating process gives an opportunity to filter out and raise the talents.

There are five main objectives of the performance management system applied by the organization which are the following:

- Synchronization of goals: synchronizing the individual goals with the organizational and business plans in order to ranking the activities.

- Accountability: establishing the accountability of employees and managers to fulfil the commitments and furthermore making an opportunity to acknowledge the successes and to recognize the difficulties.

- Differentiation: determining the difference between performance and values supporting the growth.

- Development: developing the skill levels and competences of workers in accordance with the corporate demands.

- Coaching: providing coaching and a particular, executable feedback at the right time.

The classification is performed on the basis of two main viewpoints; means of these ones gives the final overall value. One of the viewpoints is "what" the worker does to reach the goals set by himself / herself. In case of these values, as far as possible, objective indices should be applied in comparison with the performance achieved in the previous year. The other viewpoint is the "how". This viewpoint examines how the worker works for the realization of values supporting the growth. Here, all five values should be considered one by one.

Achievement of both viewpoints is evaluated on a three-graded scale and the levels 
Németh Z., Dajnoki K., Sütő D., Fenyves V. (2016)

Examination of performance management targets in case of an international corporation's eastern hungarian operating unit

are the following: it exceeds the expectations, it meets the expectations or it performs weakly. Table 1 illustrates the final results which come into being as a matrix of the two viewpoints.

Basis of the annual performance evaluation is that the worker shall set his/her particular annual goals and objectives. This process is a top-down process, a contrary of the performance management process. In this case, namely, the global corporate goals are determined at first, the particular functional organizations work up their goals in order to achieve the global goals, then the management adjust its personal goal to it and then each subordinate adjusts his/her own goals to the goals of his/her own functional manager and the process goes on this way.

Table 1 Matrix of classifications

\begin{tabular}{|c|c|c|}
\hline $\begin{array}{c}\text { "What" classification of } \\
\text { performance }\end{array}$ & $\begin{array}{c}\text { "How" classification of values } \\
\text { supporting the growth }\end{array}$ & Comprehensive classification \\
\hline Exceeds the expectations & Exceeds the expectations & Exemplar \\
\hline Exceeds the expectations & Meets the expectations & \multirow{2}{*}{ Performs eminently } \\
\hline Meets the expectations & Exceeds the expectations & \multirow{2}{*}{ Performs properly } \\
\hline Meets the expectations & Meets the expectations & \multirow{2}{*}{ Performs weakly } \\
\hline Exceeds the expectations & Performs weakly & \\
\hline Meets the expectations & Performs weakly & \multirow{2}{*}{ Performance is unsatisfactory } \\
\hline Performs weakly & Exceeds the expectations
\end{tabular}

Source: External documents of the examined organization: Employee Management System - EMS Management Guide

There will be opportunity to change these goals in the course of the year since it may occur that a given worker will get new position and therefore the system of preference will change. It is important that the employees should set their goals in such way that those ones can reflect the future career plans of the employees and the developments modes of those areas to be developed which were stated in the prior year.

At the beginning of each year, Chairman-CEO of the business lists those business goals of GE Lighting to which the individual goals will be adapted later. The most pronounced ones among the main goals set in recent years are the following:

- Leading with Financials - Implementing cost reduction projects

- Green Solution - Developing energy-efficient products

- Operational Excellence - Improving the workflows

- Commercial Transformation - Improving the commercial activities

- Energized Team - Strengthening the involvement of workers

In case of the goals mentioned above, it is important that the goals shall be selected

DE GRUYTER OPEN 
Németh Z., Dajnoki K., Sütő D., Fenyves V. (2016)

Examination of performance management targets in case of an international corporation's eastern hungarian operating unit

according to the well-known SMART criteria. In addition to the business goals, it is worth expressing a sort of personal goal which can motivate the person who expresses the goals. Examples might be the professional development, further training of language etc. Then, they will discuss their objectives with their managers and the objective will be recorded in MyGoals system after the approval of the managers. At the year-end annual performance evaluation, both the worker and his/her manager investigate the achievement of objectives.

Insofar as an employee gets into the category of "Performs weakly" then he/she cannot always carry out his/her work keeping abreast of the changing expectations and he/she fulfils the dynamical targets late. His/her work does not result in more, better, faster, cheaper and bigger customer effects or he/she needs a particular guidance to reach it as well as he/she is waiting for further instructions if he/she faces new challenges. He/she does not adequately improve his/her abilities to meet the changing business requirements as well as he/she should develop in the area of quality and competence of his/her work and complying with the deadline. He/she just preferably reacts upon the problems and possibilities instead of being ready for those ones and he/she requires instructions and monitoring more than the usual.

Those employees belong to the category of "Meets the expectations" who always perform their works keeping up with the changing expectations and fulfil the dynamical targets. Their works usually result in more, better, faster, cheaper and bigger customer effects. They rapidly react upon the new challenges, and they solve the problems in time. They always comply with their obligations, furthermore, they continuously improve their skills and they are willing to undertake tasks with larger responsibility.

Those workers who "exceed the expectations" always perform their works exceeding the changing expectations and the challenging dynamical targets. Their works result in more, better, faster, more cost-effective and bigger customer effects. They prepare for the new challenges in advance and they work out creative solutions for handling those ones.

With interests of the corporate unit in mind, they think beyond the prompt task, looking to the future. They continuously improve their skills and they voluntarily undertake tasks with larger responsibility.

\subsection{Roles of values supporting the growth}

To enhance the performance, the managers should be able to measure the strengths and development needs of workers as well as their contributions to the success of organization exactly. With regard to values supporting the growth, both the worker and the manager performing the evaluation should consider in which areas he/she has strengths and in which area the evaluated person needs to be improved.

30 DE GRUYTER OPEN
Studia Universitatis "Vasile Goldis" Arad. Economics Series Vol 26 Issue 2/2016 ISSN: 1584-2339; (online) ISSN: 2285 - 3065.

Web: publicatii.uvvg.ro/index.php/studiaeconomia.Pages $23-37$ 
Németh Z., Dajnoki K., Sütő D., Fenyves V. (2016)

Examination of performance management targets in case of an international corporation's eastern hungarian operating unit

Those abilities and positive behaviours can be strengths which materialize in the co-workers' performance of the last year. These ones shall contain those behaviours positively influencing, personal attributes and professional abilities which characterize the evaluated person. Here, those areas should also be mentioned where the employees progressed during the evaluated year and he/she can build on these attributes in the future as well.

The developmental needs include those behaviours, the missing skills and the abilities to be improved which hinder the co-workers in being a better leader or worker as well as include those ones which are to be improved so that a co-worker can reach the next level in his/her career planned. Each employee has an opportunity to progress further i.e. there is no such worker who has no developmental needs. Here, both the worker to be evaluated and the evaluation person shall find those targets and objectives which contain behaviours, knowledge and skills being necessary to reach the next career level.

This drafting reflects a positive attitude for the workers since the given shall not be ranged among the category of strengths and weaknesses but among the category of strengths and developmental needs as well as areas to be developed.

Looking outwards: its aim is that the workers will build effective relations with a wide range of the persons holding shares in the company, they will be attuned to the external customers, they will be far-seeing as well as informed and they will be curious about the global issues.

Clear thinking: its main viewpoints are that the employees have to manage the uncertainty and contradiction well and they can exceedingly adapt themselves to the changing environment. It is important that they should be in possession of firm decision-making skill and they should use their expertise and relations acquired well.

Aim of the creative imagination and courage is that the workers will come up with innovative ideas which can be achieved where appropriate. This value encourages the risk-taking and the importance of learning from the successes and failures. Its essence is to query the needless bureaucracy and the unnecessary work, to accelerate and simplify the workflows by means of creative ideas.

The value of inclusion represents that the employees should welcome the different ideas and thoughts, they should listen to opinions of others. It contributes to the cooperation and helps to respect the individuals and the different cultures. This incites the commitment and responsibility.

The value of expertise expects everyone to know his/her special field as best as possible, it requires credibility as well as it builds upon experiences and results. The expectations include the following: the worker has to undergo training continuously, he/she has to utilize the opportunities given by the technology and 
Németh Z., Dajnoki K., Sütő D., Fenyves V. (2016)

Examination of performance management targets in case of an international corporation's eastern hungarian operating unit

he/she has to improve the commitment of others as well.

The expectations relating to the elements of growth are varied with regard to every career band. The career bands are groups of such workers who have similar responsibility levels, who are in the same decision-making positions, who possess similar skills, experiences and areas to be developed. These are groupings of general nature thus various jobs and levels can be found within a career band.

Every value supporting the growth has several sub-points, based on which the workers are assessed (Figure 2).

Figure 2 Levels of values supporting the growth

\section{FORMATION}

(SEB/VP)

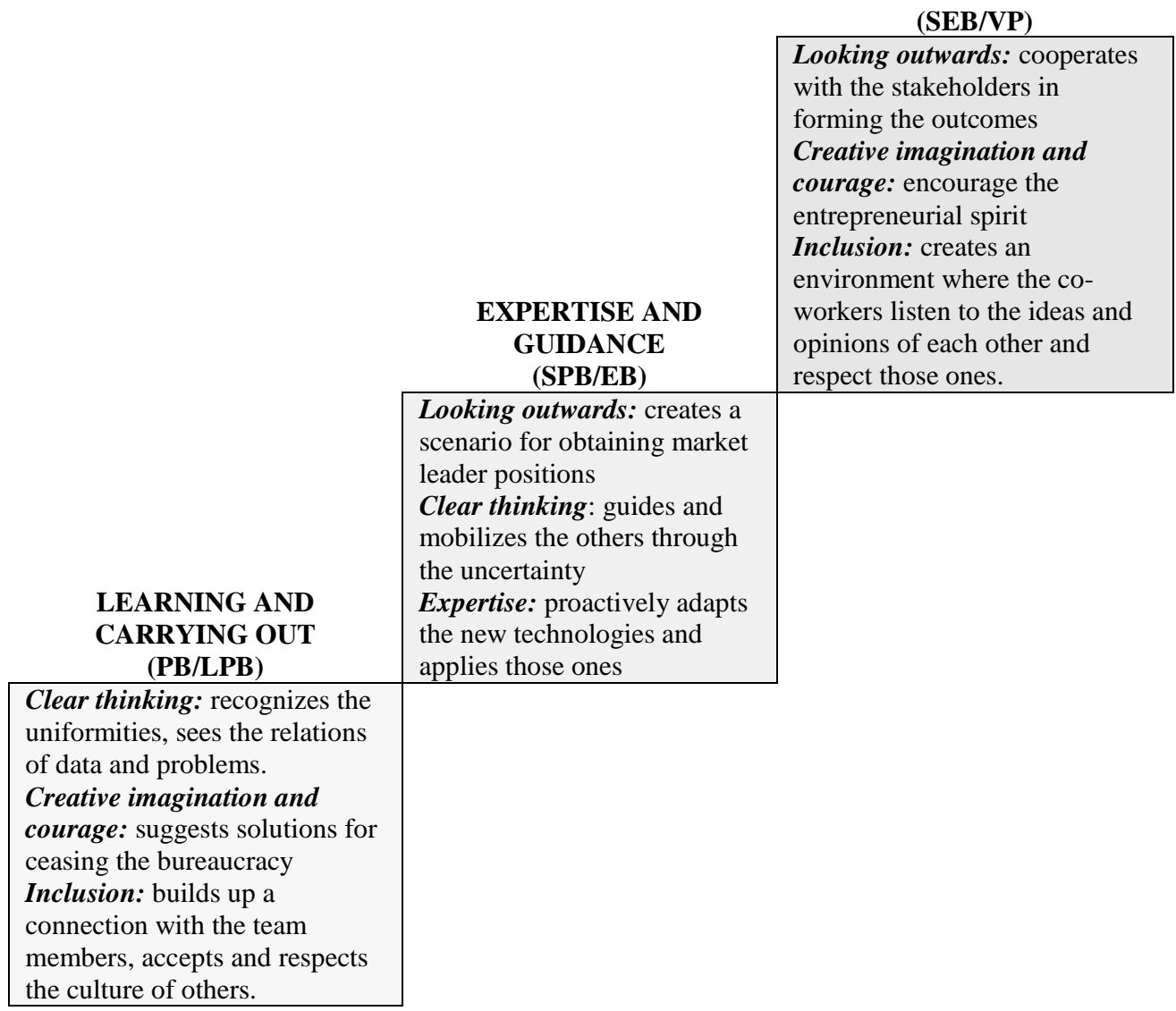

Source: External documents of the examined organization: Employee Management System

- EMS Management Guide Period of years 2011/12. 
Németh Z., Dajnoki K., Sütő D., Fenyves V. (2016)

Examination of performance management targets in case of an international corporation's eastern hungarian operating unit

Of course, not each sub-point can be interpreted to each job since these ones describe one typical behaviour each.

Ranging among certain career bands is based on the extent of responsibility, the nature of job, the business knowledge and the professional adjudication as well as the experience during the work and the expertise. Based on these properties, we distinguish 8 career bands in total. However, a corporation examines the compliance with values with regard to four main career bands.

The first one is the category of Associate Professional Band/Other Saleried (APB/OTHSAL) which usually covers the career-starter employees.

After that, there are the levels of Professional Band (PB) and Lead Professional Band (LPB) which include the experts having a few years' experience.

Categories of Senior Professional Band (SPB) and Executive Band (EB) are classification at senior and intermediate manager levels.

And, top managers of the corporation can be found at Senior Executive Band (SEB) and VB career levels.

Based on this, it is understandable that there are different expectations with regard to a person working in a lower career band and a person working at a higher, managerial level. Taking the different career bands into account, let's have a look at the values of looking outwards through an example of the customer orientation. At the first level, in the career band of APB/OTHSAL, those workers meet the expectations in subject of customer orientation who evaluate the opportunities based on the customer demands. In case of the career band of $\mathrm{PB} / \mathrm{LPB}$, it is already necessary to meet the expectations that an employee can assess the alternative opportunities and can make decisions considering the customer demands. The expectations will be exceeded if an employee elaborates and introduces processes and solutions according to the points of view of the customer as well as he/she also considers the effects.

Conversely, at the level of SPB/EB, the expectations against the workers are even higher than the above-mentioned. Here, it is already important that the worker should know the customers of GE, their business strategy, rivals and main sources of revenue. If he/she wants an exemplar then he/she shall utilize his/her industry contacts in order to provide information for the customers about their own branches of industry, competitors and customers considering that such long-lasting relations should be established which are advantageous and profitable for both parties.

And, at the career level of SEB/VP, the employees shall create and maintain such a culture which esteems and incites the long-lasting customer relations. The strategic relations elaborated with the customers and partners shall be utilized for the benefit of whole of the company examined. It is important to prepare for the changes of 
Németh Z., Dajnoki K., Sütő D., Fenyves V. (2016)

Examination of performance management targets in case of an international corporation's eastern hungarian operating unit

market and the external trends so that effective solutions should be introduced into the market before the competitors.

After the customer orientation, let's see what effective abilities and skills shall be available in case of the growth supporting value of clear thinking. In this respect, the employee handles the uncertainty and contradictions well so he/she can adjust to the different situations well. He/she interconnects the strategy with the goals and communicates inspiringly.

For making decisions, he/she uses relevant information originating from different sources, he/she ponders more alternatives and evaluates the potential solutions, he/she uses his/her knowledge, expertise, contacts and intuitions well. He/she considers the short- and long-term effects of actions on the efficiency of business activity. He/she concentrates on the main goals and tasks even in case of a change in the order of importance as well and he/she modifies the focus if necessary. $\mathrm{He} / \mathrm{she}$ passes the information of key importance to the appropriate persons effectively, straightforwardly and in time.

We can find different expectations at the level of creative imagination and courage as well. An outstanding colleague has so many ideas, in addition, he/she also urges others to brainstorm, he/she is initiative in adopting new methods and supports the changes. He/she confidently responds to opinions of others and is able to make difficult decisions if necessary. He/she creatively solves the difficult challenges and strives for the success. He/she suggests solutions, develops new methods for ceasing the bureaucratic workflows without value added. He/she provides an open environment so that daring and individual ideas can outcrop and he/she supports the valuable proposes. He/she expounds the successes and fiascos as possibilities for growing, he/she divides the learned thing between others and he/she introduces changes in order to avoid the repetition of fiascos. He/she creates such an environment vesting the workers with power which supports the honest assumption of risk where experimentation is required and which extends the limits. He/she puts his/her personal trustworthiness and good reputation into action in order to persuade anyone of what he/she believes in.

$\mathrm{He} / \mathrm{she}$ creates such a culture where simplicity and efficiency of the organization is a key prime mover of the business activity as well as he/she establishes such an environment where every worker gives open and constructive feedback to each other regardless of who is boss or at what level of the hierarchy the given worker works.

An ideal representative of the inclusion as an the fourth value supporting the growth searches for the possibility for cooperation and indeed, proactively cooperates in finding solutions while he/she gleans the tasks and inspires others as well as offers help whenever he/she can. He/she asks thought-provoking questions

34 DE GRUYTER OPEN
Studia Universitatis "Vasile Goldis" Arad. Economics Series Vol 26 Issue 2/2016 ISSN: 1584-2339; (online) ISSN: 2285 - 3065.

Web: publicatii.uvvg.ro/index.php/studiaeconomia.Pages $23-37$ 
Németh Z., Dajnoki K., Sütő D., Fenyves V. (2016)

Examination of performance management targets in case of an international corporation's eastern hungarian operating unit

in order to launch dialogue and disputes for discussing the problems and accepting new ideas thus he/she gets the others to step out of the area limited by the usual paradigms and to see the things from several aspects. He/she recognizes the fine signals of others and actively searches of the necessary information and the opportunity for clarification. He/she changes his/her attitude in order to consider demands and viewpoints of others. He/she is connected with different teams in numerous areas, he/she gets to know, accepts and respects their culture, he/she identifies the different viewpoints and supports that the opinions should originate from different sources.

$\mathrm{He} / \mathrm{she}$ praises the others and searches for opportunities to admit the individual and team performances. He/she creates such an environment where the workers listen to the opinions and ideas of others and respect those ones. He/she compiles variegated teams and takes advantage of the differences between individuals; he/she recognizes the similarity between the team members. In the global team, he/she attunes everyone for sake of the common goal, showing the role of respect, sensitivity and cultural tolerance. He/she establishes culture which is based on cooperation and, for this end, he/she places a model and emphasizes as well as rewards the cooperation between the teams.

The expert also utilizes the experiences originating from outside of the limits of corporate activity (state, authority, civil society organizations etc.) in order to establish the competitive advantages, decrease the risks and to grow. He/she inspires the organizations to compare themselves to the best of the category in order to recognize the front-line technologies and to apply the learned things. $\mathrm{He} / \mathrm{she}$ continuously assesses the deficiencies of the personal development; he/she knows his/her way around even in case of the chase of environment as well. He/she works out an organizational culture based on learning and development; he/she takes part in developing others and enthuses over it. His/her front-line and innovative ideas relating to the sector and his/her field of work are acknowledged. $\mathrm{He} / \mathrm{she}$ searches for, employs and promotes the local talents in order to utilize the market opportunities and to establish the stable reinforcement. Insofar as an employee meets the requirements of the career band listed above then he/she will get the valuation of "Meets the expectation".

Insofar as he/she cannot meet these expectations then he/she will get into the category of "Performs weakly". If he/she over fulfils the under mentioned conditions then he/she will get the valuation of "Exceeds the expectations" in the category of growth values. Of course, the expectations being at higher level suppose that conditions of the lower career band have already been met. However, the criteria shall always be met at all levels in such way that the major guiding 
Németh Z., Dajnoki K., Sütő D., Fenyves V. (2016)

Examination of performance management targets in case of an international corporation's eastern hungarian operating unit

principle of the corporation examined i.e. the principle of "Always unbroken probity" is borne in mind in the meanwhile.

\section{Conclusions}

Based on the results, it can overall be stated that such a well-functioning performance management system is applied in the operating unit of the corporation examined which is strongly supported by the organizational culture and which contributes to the joint fulfilment of personal as well as organizational goals.

The values explored by means of the methods of case study and document analysis are throwing light upon that the challenges arising in areas of corporate operation are successfully completed in the organization examined, the performance management, with its each function, strives to increase the economic productivity and to preserve the competitiveness as well as to retain and enhance the satisfaction of employees. Based on the examinations, it can be expressed that the applied performance management is in full compliance with the function developing the human resources, its relation with the function ensuring, supporting and inciting the human resources is based on the refining. In the organization examined, not only performance evaluation is performed but real performance management operates which forms an integrated system with the different HR functions by means of the well-considered individual and organizational goals. Strategy and objectives of the company are stated at the highest levels, at the same time these can be decoded, concretized and realized well in real life. During the examinations, it was proven that the performance evaluation is in closer connection with the development of human resources in consequence of its performance orientation, therefore the assessment of satisfaction fades into the background. In case of the feedback of performance evaluation, there is no control system installed which can hinder the subjective assessment such as in case of the classification of manual workers performed by their shift leaders. It would contribute to smooth operation of the workflows if both the direct and indirect workers were able to see clearly what tasks and problems are waiting for solution at level of shift leader and factory manager and what cases require the help of HR Team.

\section{References}

1. Allen, D.G. (2008): Retaining Talent. SHRM Foundation, Alexandria, USA, 57

2. Armstrong, M. (2006a): Performance Management, Kogan Page, London, 224.

3. Armstrong, M. (2006b): A Handbook of Human Resource Management Practice, Kogan Page, London, 957.

4. Bacsne Baba E. (2012): Idovizsgalatok vezetesi es szervezeti folyamatokban. VIKEK IV. evf. 5. szam (No. 11) A sorozat, 3. Szeged, Hungary, 5-14.

5. Becker, B.E. \& Huselid, M.A. (2006): Strategic human resource management: Where

36 DE GRUYTER OPEN
Studia Universitatis "Vasile Goldis" Arad. Economics Series Vol 26 Issue 2/2016 ISSN: 1584-2339; (online) ISSN: 2285 - 3065.

Web: publicatii.uvvg.ro/index.php/studiaeconomia.Pages $23-37$ 
Németh Z., Dajnoki K., Sütő D., Fenyves V. (2016)

Examination of performance management targets in case of an international corporation's eastern hungarian operating unit

do we go from here? Journal of Management, Vol 32. No. 6, 898-925.

6. Dessler, G. (2012): Human Resource Management. Prentice Hall, New Jersey, 720

7. Dessler, G. (2013): Human Resource Management. Pearson Education, 718.

8. Draganescu, D. \& Lupuleasa, D. \& Dumitrescu, B. \& Taerel, A. E. \& Ciolan, D. F. (2013): The non-discrimination principles - component of the implementation of Longlife Learning Program. Implementation specificity for pharmaceutical field, Studia Universitatis "Vasile Goldis", Seria Stiintele Vietii, Vol. 23, issue 3, 2013, p. 342. http://www.studiauniversitatis.ro/pdf/23-2013/23-3-2013/SU23-3-2013-Draganescu.pdf 9. Gergely, E. \& Dienesne Kovacs E. (2010): Analysis of human resource management fields at profit-making organizations. VIKEK No. 3-4., Szeged, Hungary, 79-84.

10. Goleman, D. (2002): Erzelmi intelligencia a munkahelyen. Edge $2000 \mathrm{Kft}$, Budapest 514.

11. IRS (2003): Trends in Performance Management. Employment Review, $1^{\text {st }}$ August 2003, 12-19.

12. Iveta, G. (2012): Human Resources Key Performance Indicators. Journal of Competitiveness, Vol. 4, Issue 1, 117-128.

13. Jebereanu, L. \& Jebereanu S. A. \& Vlaicu B. \& Pauncu E-A. (2013): Risk factors and health status of a group of workers exposed at waste water in Timisoara city, Studia Universitatis "Vasile Goldis", Seria Stiintele Vietii, Vol. 23, issue 2, p. 168. http://www.studiauniversitatis.ro/pdf/23-2013/23-2-2013/SU23-2-2013-Jebereanu.pdf

14. Karoliny M-ne (2010): Attekintes az emberi eroforras menedzsmentrol. In: Karoliny M.-ne \& Poór J. (eds.) Emberi eroforras menedzsment kezikönyv. Rendszerek es alkalmazasok (pp. 23-54) Complex Kiadó, Budapest

15. Laezar, E. P. (2006): A human eroforrasok közgazdasagtana vallalati vezetok reszere. Budapest, Nemzeti Tankönyvkiadó 500-503.

16. Max, D. \& Bacal, R. (2002): Perfect Phrases for Performance Reviews. Hundreds of Ready to Use Phrases That Describe Your Employees' Performance. McGraw-Hill, New York, 13-14.

17. McKenna, E. \& Beech, N. (1995): The Essence of Human Resource Management, Prentice Hall Europe, Simon \& Schuster Company.

18. Pulakos, E.D. (2004): Performance Management. SHRM Foundation, Alexandria, USA, 56.

19. Sartain, L. (2004): Hetköznapi emberekbol rendkívuli eredmenyeket kihozni. In: Efron, M., Gandossy, R. \& Goldsmith, M. (eds) HR a 21. szazadban (pp. 23-31) HVG Kiadói Rt., Budapest

20. Senyucel, Z. (2009): Managing the Human Resource in the $21^{\text {st }}$ Century. Zorlu Senyucel \& Ventus Publishing ApS., 77.

21. Snell, S. \& Bohlander G. (2003): Managing Human Resources. South-Western College Pub. 832.

22. Spencer, L.M. \& Spencer, S.M. (1993): Competence at Work. New York, Wiley. 372.

DE GRUYTER OPEN
Studia Universitatis "Vasile Goldis" Arad. Economics Series Vol 26 Issue 2/2016 ISSN: 1584-2339; (online) ISSN: 2285 - 3065

Web: publicatii.uvvg.ro/index.php/studiaeconomia.Pages $23-37$ 